\title{
APPROACHES TO GOVERNMENTAL LIABILITY IN TORT: A COMPARATIVE SURVEY
}

\author{
Frederick F. Blachly* and Miriam E. Oatman**
}

The rapid growth of public services and functions in most countries, the large number of persons engaged in the civil service or in the military forces, and the increase in the number of risks brought about by mechanisms such as the automobile, the airplane, and other methods of transportation, mean that an ever-increasing number of persons will suffer injuries resulting from governmental acts and operations. A problem of great importance, then, is that of the responsibility of the state and its agents for such injuries.

The solution of this problem involves considerations dealing with: The nature of the state; an ethical basis for the establishment of responsibility; a legal basis for the establishment of responsibility; the types of action for which the state and its agents should be responsible; the persons to whom it should be responsible; and the relationship that should exist between the state and its subdivisions and agents. In addition to these theoretical considerations, attention must be given to a number of practical problems, such as: How should claims against the state and its agents be handled? How shall the divisions of government meet their obligations? What is the best method of protecting officers in their governmental duties? Can one system of responsibility be established that is applicable to all divisions of government?

No two countries have solved their problem of responsibility in the same way. This is due largely to the historical circumstances under which the systems have been developed. An attempt will be made in this paper to summarize the ways in which the responsibility of the state and its agents for tort are solved in England, the United States, Germany, and France, and to establish a theoretical and practical basis for the more satisfactory solution of the problem in the United States. Responsibility will be examined in these various countries, so far as possible, as it exists in the three chief

- A.B., I9II, Oberlin College; Ph.D., I916, Columbia University. Member of the senior staff of the Brookings Institution, Washington, D. C.; Professor of Government, University of Oklahoma, 1916-1925. Co-author with Dr. 'M. E. Oatman: Federal Regulatory Action and Control (1940); Comparattve Governafent (I937); Administrative Legislation aND ADJUdication (I934); The GovernMENT AND Administration of Germany (1928); Some Problems in Oklahoma Finance (1924); The Government of OrLahoma (1924); Everyday Cituzenstip (1920).

* A.B., I912, Oberlin College; M.A., 1924, Columbia University; Ph.D., I928, Brookings Institution. Associate Reference Librarian, Library of Congress, Washington, D. C. Co-author with Frederick F. Blachly of the books listed in the preceding paragraph, and of SEN. Docs. Nos. 52, I47, Strikes in Defense Industries, 77th Cong., Ist Sess. (194r). 
units of government (central, state or regional, and local). Some attention will then be given to the responsibility of officers.

\section{The English System}

The English system of responsibility of the state and its agents appears to be the outgrowth of a long series of historical events and circumstances, rather than the result of any well-considered and systematic plan. Some of its features have their roots in feudalism; much of it is traceable to political theories developed when the "divine right of kings" theory was in full bloom; parts of it are the results of statutory enactment; but even more it is built upon court decisions, some of which embody feudal concepts and the political theories of the Middle Ages.

\section{The responsibility of the central government.}

The system of responsibility of the central government in England centers around the position of the Crown. During earlier feudal times the King did not possess the transcendental qualities with which he was later endowed by theologians, political philosophers and lawyers. The King was not the state; and although he could not be sued, this was due merely to the old principle that no feudal lord could be sued in his own courts. ${ }^{1}$

As late as the thirteenth century it was recognized that the King could act illegally. At the same time, special prerogatives of the King were developing; and in many instances the ground of public utility was made the basis of the King's claim that he was above the law. There was, however, a general recognition of the principle that he was bound by the law of God to do right.

The early Christian fathers regarded government as a divine institution. During the Middle Ages legal theory, influenced by ecclesiastical doctrines, developed the principle that the sovereign holds his position by divine right and is therefore not subordinate to man-made law. Bracton's thirteenth-century commentary upon English law gives a blending of the two views of the sovereign's position; the lawyer's, that the King is subordinate to the law, and the theologian's, that the King is the Vicar of God and as such is not subject to the control of man.

"The King does not have an equal in his kingdom. . . . But the King himself ought not to be under mankind, but under God and under the law, since the law makes the King." Again: "But for this purpose the King was created and chosen, that he shall do justice to all. ... But the King is not able to do anything else on earth, since he is the minister and vicar of God, except that alone which he is able to do of right. ... Thus his power is of right and not of wrong, and since he is the author of right, the occasion of wrongs ought not to arise; and indeed, he who must necessarily prohibit others [from wrong] because of his office, should not in his own person commit it."2

\footnotetext{
${ }^{2}$ Pollock and Maitland say: "He cannot be compelled to answer in his own court, but this is true of every petty lord of every petty manor. ..." I History of English Law (2d ed. 1923) 518 . Holdsworth says he could not be sued in central courts of law because they were his courts "and no lord could be sued in his own court." A History of Remedies Against the Crown (1922) 38 L. Q. REv. I4I, at I42.

2 Bracton, De Legibus ET Consuetudinibus Angliae (Woodbine's ed. 1922) (writers' translation).
} 
In another passage Bracton displays a double viewpoint in respect to methods of controlling the King, when he says: "But if it be a prince or a king, or another who has no superior unless the Lord, there will be no remedy against him by assize, on the contrary, there will ever be place for a supplication that he will correct and amend, which if he will not do, it must suffice for him to await the Lord, the avenger, who says: 'To me vengeance, I will repay,' unless there be some who says, that the body corporate of the realm and the body of barons ought to do this and may do it in the court of the King himself." 3

As a result of feudal theory, then, we have the basis for much of the present-day theory of irresponsibility of the State. This theory, holding that the King can do no wrong; that he is irresponsible before the law of man; that he cannot be sued; but that the right of supplication exists, bears a close resemblance to certain contemporary ideas which will be discussed presently.

In order to explain and justify the important changes that resulted from the downfall of the feudal system, with the waning power of the great nobles and the increased power of the sovereign, ingenious doctrines were developed by political theorists, theologians, and judges. The chief of these defined sovereignty, personified the Crown as the state, and applied the principle that the King can do no wrong.

The doctrine that sovereignty is the highest power of the state, that it is subject to no law, but is itself the creator of law, and that it resides in the monarch, did much to place the state in a position of irresponsibility for its torts. Although the King of England did not, as in Spain and France, become indistinguishable from the state, yet the personification of the Crown as the state led to the adoption of the idea that sovereignty was an attribute of the head of the state. This idea, combined with the great prerogative powers which the King had developed, virtually placed the King in an untouchable position.

Because the King is sovereign, Blackstone, writing toward the end of the eighteenth century, is able to say: "... no suit or action can be brought against the King, even in civil matters, because no court can have jurisdiction over him. For all jurisdiction implies superiority of power: authority to try would be vain and idle, without an authority to redress; and the sentence of a court would be contemptible, unless that court had power to command the execution of it: but who, says Finch, shall command the King?"4 Legally, then, the King would not be responsible for tort; for as Blackstone again says: "No jurisdiction upon earth has power to try him in a criminal way; much less to condemn him to punishment."

The maxim that "the King can do no wrong" became fully developed by this time, and has since continued in force. This maxim applies not only to wrongs done personally by the sovereign, but also "to injuries done to a subject by the Authority of the Sovereign." Not only can the King do no wrong, but he cannot authorize

\footnotetext{
${ }^{3}$ Bracton, De Legibus et Consuetudinibus Angliae (Twiss' ed. 1878-1883).

- I Blackstone, Commentarues (9th ed. 1783 ) 242.

sibid.

- Feather v. The Queen, 6 B. \& S., 257, 292, I22 Eng. Rep. II9I (Q. B. 1865).
} 
wrong, since a wrongful act is regarded by law as the act of the one who authorized it. The personality of the Crown has been widely extended to "emanations of the Crown," including certain officers, boards, commissions, and other authorities. A corollary of this doctrine is that any wrongful act in connection with the exercise of the public power is considered by law as the act of the person who did it, and not the act of the sovereign or of his symbolic office or authority, called the Crown. The result of this doctrine is that officers can be held responsible in person for their tortious acts.

Although remedies against certain types of Crown action developed from the time of Henry III on, such as the petition of right, the traverse of facts, the petition of grace, the monstrans de droit, and the possibility of equitable relief against the Crown, by none of them could the individual receive relief from torts. This applies also to the petition of right, which was revived during the early part of the nineteenth century so as to apply to a much wider field than during the fifteenth and sixteenth centuries. $^{7}$

A committee appointed in 1921 by the Lord High Chancellor to consider the position of the Crown as litigant, to propose desirable amendments to the law, and to prepare a bill embodying recommended changes, advocated in its report: (a) That the Crown, with certain reservations, should be placed in the same position as the subject with reference to power to sue and be sued; (b) that the Crown should become liable to be sued in tort; (c) that the Crown should have the same capacity to recover, and the same liability to pay costs, as the subject litigant. The bill as drawn up by the committee provided for these changes. It was not passed by Parliament. $^{8}$

\section{The responsibility of officers.}

Even as early as the time of Henry III, the King ruled less in person than through his officers. Consent of the King had to be given before the King's officers could be sued. According to Bracton, if a bailiff or a servant of the King disseized one of property in the name of the King, a writ for recovery should be taken, but judgment should not be given before the will of the King was known. ${ }^{9}$ In other words, according to Ehrlich, ${ }^{10}$ judgment could not be given unless the King disclaimed the act. The Statute of Westminster I of 1275 abolished the presumption in favor of the King's order and the resulting inadmissibility of a judgment without his disclaimer. The possibility of redress by the King himself was preserved and a writ of novel disseisin was given against the aggressor. ${ }^{11}$ At this time the acts of the King's servants could not be questioned in ordinary ways. Their acts were considered as acts of the King, and no complaint would lie against them except to the King or to

\footnotetext{
${ }^{7}$ See Ehrlich, Petitions of Right (1929) 45 L. Q. REv., 60, 62; Morgan, Remedies Against the Crown, introd. chapter in G. Robinson, Public Authority AND Legat Linbility (1925).

${ }^{8}$ See Crown Proceedings Committee: Report. Command Paper No. 2842 (1927).

${ }^{\circ}$ BrActon, op. cit. supra note 3 , I7rb, I72a.

${ }^{10}$ Proceenings Aganst the Crown (I921) $51 . \quad{ }^{11}$ Ibid.
} 
bodies appointed by him for that purpose. When the King did assume responsibilitythe only redress was a petition to him. ${ }^{12}$

During the time of Edward I, the King gradually waived his privilege of giving consent to have his officers sued. The Statute of Westminster II of 1285 provided that persons illegally imprisoned by sheriffs should have action by a writ of false imprisonment against the sheriffs and action against bailiffs of franchises. ${ }^{13}$ On the other hand, although during the reigns of Edward II and Edward III it was possible to complain against actions of royal officers by petition, the King's orders were considered a good justification of an otherwise unlawful act. Since the privilege of not being sued at common law for official acts was a privilege in favor of the King and not his officers, when the King waived his right, the officer could be sued in the ordinary courts. By the end of the fifteenth century the idea that if wrong were done by an agent of the King the agent alone should be liable was beginning to be recognized..$^{14}$ Two hundred years later the doctrine developed that the King's command affords no immunity to officers of the King. High officers of state and all their subordinates must answer before the ordinary law for any crime or wrong committed by them. No longer could they plead obedience to royal orders. ${ }^{15}$

The present-day situation of officers is given by Dicey, ${ }^{16}$ who says: "In England the idea of legal equality, or of the universal subjection of all classes to one law administered by the ordinary Courts, has been pushed to its utmost limit. With us every official, from the Prime Minister down to a constable or a collector of taxes, is under the same responsibility for every act done without legal justification as any other citizen. The Reports abound in cases in which officials have been brought before the Courts, and made, in their personal capacity, liable to punishment, or to the payment of damages, for acts done in their official character but in excess of their lawful authority. A colonial governor, a secretary of state, a military officer, and all subordinates, though carrying out the commands of their official superiors, are as responsible for any act which the law does not authorize as any private and unofficial person."

\section{The responsibility of local authorities.}

Two important considerations must be kept in mind in the attempt to determine the responsibility of local authorities: (I) the extent to which local authorities are controlled by the central authorities, and (2) the distinction as to whether the state imposes duties upon them; or merely confers powers.

r. Local administrative authorities which do not come within the classification of "emanations of the Crown" are generally liable for the acts of their servants, under the doctrine of respondeat superior. There, are, however, many exceptions to this rule, as follows:

${ }^{12} I d$. at IIr.

14 Pollock and Maitland, A History of Remedies Against the Crown, loc. cit. supra note X, at 154 .

15 "The warrant of no man, not even the King himself, can excuse the doing of an illegal act." Sand v. Child, 3 Lev. 352,83 Eng. Rep. 725 (K. B.).

${ }^{26}$ Introdection to the Study of the LAT OF the Constitution (7th ed. 1908) 189. 
a. The local government is not liable where its agent is performing duties imposed specifically upon him by the central government, for the reason that in the performance of such acts the agent is not considered a servant of the local authority.

b. The local government is not liable when the relationship of master and servant does not obtain between the local authority and the person performing acts for it. Here the courts have followed the common law doctrine that a man is not liable for every appointment which he makes, and that the factor of appointment does not create a relation of master and servant. There must be a certain degree of control over the servant on the part of the master. ${ }^{17}$ Other factors are the question of the power to discharge, and the question of by whom the payment is made.18

c. Where local authorities are merely performing ministerial duties imposed upon them, they are not liable. This is particularly true when the local authority is a part of a larger administrative machine carrying out a definite function, and even more so where the chief authority of that machine is an "emanation of the Crown."

d. Where, however, an express statutory duty is imposed upon the local authority, even if it is in a general way subject to the control of the central authority, it is nevertheless liable for the acts of its servants.

e. The local authority is not responsible for ultra vires acts of its servants.

2. In deciding questions of liability, the distinction must be made between duties which are imposed and optional functions. When duties are imposed upon local authorities either by royal grant or by statute, an indictment will lie for nonperformance, and an action for damage in a private suit will be permitted.

Another distinction must be made as to whether when duties are imposed by statute, the act complained of is one of nonfeasance or misfeasance. The local authorities are not liable for nonfeasance, unless the legislature has clearly expressed such an intent. A damage action will lie, however, where there has been a definite invasion of the legal rights of an individual from nonfeasance. Where statutes prescribe positive duties, authorities acting under them are responsible when a subjective or personal legal right has been infringed. The distinctions made between nonfeasance and misfeasance are often so hairsplitting that they are quite beyond the comprehension of minds other than those of the very learned judges making them. The basic principles governing local responsibility are thus far different from those governing the responsibility of the current government.

\section{Summary}

Let us summarize in a few words the English system. In the first place, it is divided into three parts: ( $x$ ) the responsibility of the central government; (2) the responsibility of officers; and (3) the responsibility of local governments.

The central government is not responsible for torts. The theory underlying this

${ }^{17}$ Sadler v. Henlock, 24 L. J. 138, II9 Eng. Rep. 209 (Q. B. 1855); Yewens v. Noakes, 6 Q. B. D. 530 (1880).

${ }^{18}$ See Macdonnell's Master and Servant (2d ed. 1899) c. XXVIII. On master and servant relationship see also Evans v. Mayor of Liverpool [1906] I K. B. I60; Hillyer v. Governor of St. Bartholomew's Hospital [rg09] 2 K. B. 820. 
situation is based on the broad notion that the King as the Crown represents the State, on the doctrine that the King can do no wrong, that he as sovereign is beyond law and so cannot be sued.

The liability of officers is based upon the theory that since the King can do no injustice, if injustice is done it must be done by one of his counsellors or servants. It is also based upon the English doctrine of the supremacy of the law, which means "the universal subjection of all classes to one law administered by the ordinary courts," and means also that an illegal act is an ultra vires act, which the doer cannot perform in an official capacity, but only in the capacity of an ordinary person.

The basic theories of the responsibility of local governments for torts are those of respondeat superior as a corollary of the assumption of a master and servant relationship.

\section{The United States System}

The system of responsibility for tort in the United States ${ }^{19}$ is not built upon any carefully devised plan, but is the result of a long historical development. Although modeled to a certain extent upon the English system (particularly in respect to the national and state governments), it shows many important variations in both theory and practice. The chief causes of these variations are: Differences in doctrine regarding the nature of the state; the absence of a personal authority comparable to the King to represent sovereignty; the fact that the states as well as the central government are for many purposes sovereign; the fact that municipal corporations and quasi-municipal corporations are agencies of the state and not of the federal government; and the fact that municipal authorities are organized on a different basis than in England.

\section{Responsibility of the national and state governments.}

The non-responsibility of the federal and state governments for torts is based squarely upon the doctrine of sovereignty as developed by the English courts. It takes for granted that the sovereign cannot be sued, and that in the eyes of the law the sovereign cannot commit a tort. "For the first seventy years," says Watkins, ${ }^{20}$ "the doctrine of sovereign immunity was accepted without hesitation, except in one instance, $^{21}$ and without the recognition of any necessity for explanation. . . . We adopted it without considering whether it was valid, essential, or desirable."

In 1879, the United States Supreme Court said: "The principle is elementary that a State cannot be sued in its own courts without its consent. This is a privilege of sovereignty." 22 In the case of Kawananakoa v. Polyblank, ${ }^{23}$ Mr. Justice Holmes stated, as regards the reason for this exemption: "A sovereign is exempt from suit, not because of any formal conception or obsolete theory, but on the logical and prac-

\footnotetext{
${ }^{10}$ Five sub-systems must be considered: (I) federal; (2) state; (3) municipal; (4) quasi-municipal * corporations; and (5) responsibility of officers.

20 The State as a Party Litigant (1927) 55.

${ }^{31}$ The "one instance" is Chisholm v. Georgia, 2 Dall. 4 I9 (U. S. x793).

${ }^{22}$ Railroad Co. v. Tennessec, Ior U. S. 337, 339 (1879).

${ }^{23} 205$ U. S. 349,353 (x907).
} 
tical ground that there can be no legal right as against the authority that makes the law on which the right depends." In the case of Cunningham v. Macon and Brunswick $R . R .{ }^{24} \mathrm{Mr}$. Justice Miller remarked: "It may be accepted as a point of departure unquestioned, that neither a State nor the United States can be sued as defendant in any court in this country without their consent, except in a limited class of cases in which a state may be made a party in the Supreme Court of the United States by virtue of the original jurisdiction conferred on this Court by the Constitution." In the case of Hans v. Louisiana, ${ }^{25}$ Mr. Justice Bradley, after referring to many cases, said: "The truth is, that the cognizance of suits and actions unknown to the law, and forbidden by the law, was not contemplated by the Constitution when establishing the judicial power of the United States. ...

"The suability of the State without its consent was a thing unknown to the law. This has been so often laid down and acknowledged by courts and jurists that it is hardly necessary to be formally asserted." In the same case, in a concurring opinion, Mr. Justice Harlan based the inability of a citizen to sue the State on the ground that such a suit "is not one to which the judicial power of the United States extends, unless the State itself consents to be sued."

Not only does the federal Government recognize no liability for torts, except where especial provision is made by law, but it denies that the Government can commit a tort, unless a law expressly so contemplates. This doctrine was well expressed by Justice Holmes in the case of The Western Maid, ${ }^{26}$ in which he said: "The United States has not consented to be sued for torts, and therefore it cannot be said that in a legal sense the United States has been guilty of a tort. For a tort is a tort in a legal sense only because the law has made it so."

If the state or the federal government consents to be sued, however, it may be made responsible for torts. Although the Court of Claims Act of 1855 , as amended, ${ }^{27}$ eliminated from the jurisdiction of this Court cases "sounding in tort," several recent statutes have provided either for the bringing of suits against the United States for tortious actions or for the settlement of such claims by administrative action. ${ }^{28}$

Congress has provided for the settlement of several types of claims for injury or damage through administrative action.

I. The Employees' Compensation Act of September 7, rgr6 ${ }^{20}$ made the Government liable in general for compensation to any civil employee or his dependents for disability or death "resulting from a personal injury sustained while in the performance of his duty." It set up an Employees' Compensation Commission as an

24 I0g U. S. 446,451 ( 1883 ).

${ }^{20} 257$ U. S. 419,433 (192r).

${ }^{25}$ I34 U. S. $1,15-16$ (1890).

${ }^{27} 28$ U. S. C. $\$ 250$ (1940).

${ }^{28}$ a. By 36 STAT. 85 I (r910), the Court of Claims was given jurisdiction of cases where the United States has used a patent without a license or the lawful right to use it.

b. The Court of Claims was also given jurisdiction to hear and determine claims for damages to oyster growers arising from dredging operations upon private or leased lands or bottoms. 28 U. S. C. 3250 a (I940).

See Holtzoff, The Handling of Tort Claims Against the Federal Government, infra p. 3I r. Eo.

${ }^{29} 39$ STAT. 742 (I9I6), 5 U. S. C. $\$ 751$ (1940). 
independent establishment, to administer the Act and to hear and determine all claims for compensation under it.

Other laws have extended the principle of compensation to employees of the District of Columbia, ${ }^{30}$ employees of the United States Shipping Board Merchant Fleet Corporation, ${ }^{31}$ employees of the Panama Railroad Company, ${ }^{32}$ employees of the Alaska Railroad, ${ }^{33}$ and persons employed on relief projects in the Civilian Conservation Corps, Civil Works Administration, Federal Emergency Relief Administration, and Works Progress (Works Project) Administration. ${ }^{34}$ How significant this responsibility for injuries has become may be judged from the fact that from January to June, I94I, 28,943 cases of injuries or death were reported to the Employees Compensation Commission from all of the establishments under its jurisdiction, ${ }^{35}$ and the total paid from the compensation fund was $\$ 4,980,875 .^{\mathbf{3 6}}$

2. The Chief of Engineers, subject to the approval of the Secretary of War, has authority to adjust and settle all claims not to exceed $\$ 500$ for damage or destruction caused to private property occasioned by vessels belonging to or employed by the United States. ${ }^{37}$

3. The heads of executive departments or independent establishments of the government may settle claims for damages to, or for loss of, private property by the negligence of government employees acting within the scope of their authority, not exceeding the value of $\$ 1,000 .^{38}$

\section{Liability of municipal corporations.}

In respect to torts there is a striking contrast between the national and state governments of the United States, and the municipal governments. Although the nation and the states, if they wish, may submit themselves to the jurisdiction of the courts, they may not be required to do so by compulsion of the courts; for they are considered as sovereign and therefore not suable without their consent. A municipal corporation, on the other hand, without its consent and even against its protest, must submit to any proper legal action, on the theory that it is not a sovereign body, but merely an artificial subordinate body under the complete control of the state. This seems to mean in practice that not only may the legislature place municipal corporations in the position of being responsible for torts, but that the courts may do the same, since the doctrine of municipal responsibility is largely a judicial creation.

The most general rule regarding municipal liability for tort rests upon the distinction between public and private functions. When a municipality is acting in a

${ }^{30} 4 \times$ STAT. IO4 (I9x9), as amended, 5 U. S. C. \$794 (1940).

314 STAт. 377, as amended, 5 U. S. C. $\$ 795$ (1940).

3239 STAT. 750 (I9I6), 5 U. S. C. \$791 (1940).

${ }^{33} 43$ STAT. 1356 (1925), 5 U. S. C. \$792 (I940).

36 48 STAT. 35 I (1934), 5 U. S. C. $\$ 796$ (1940). The conditions and limitations of this law are quite different from those of the original Employees' Compensation Law. 24 Rep. U. S. Compensatton Comm. (194I) I et seq.

${ }^{30}$ Id. 9 .

${ }^{80}$ Id. at 29.

${ }^{37} 36$ Stat. 676 (Igro) as amended, 33 U. S. C $\$ 564$ (I940).

${ }^{88}{ }_{42}$ STAT. 1066 (1922), 3I U. S. C. \$\$215, 216 (1940). 
governmental or public capacity, or carrying out the state's functions, it generally enjoys the same immunity as the state. This immunity, however, does not apply to its liability for failure to perform certain statutory or common law duties, such as keeping streets and highways committed to its care in a reasonably safe condition. ${ }^{30}$

When a municipality is acting in a proprietary capacity, or merely as a corporation, then, like a private individual or corporation, it is subjected by the courts to liability for the torts of its agents. In carrying out its private functions (usually those concerning which it makes a contract, or those for which it receives a money compensation), it cannot escape liability unless relieved by valid legal provision. Statutes may, of course, limit municipal liability, as for instance, by restricting such liability to particular classes of cases, ${ }^{40}$ or by making actions in tort against municipal corporations conditional upon the fulfillment of certain specified formalities.

Another distinction that is almost universally made is the distinction between nonfeasance and misfeasance. Where there is no mandatory duty to act and where failure to act does not constitute negligence, there is no ground for recovery against a municipal corporation. Hence failure to make and enforce police regulations relating to the transportation of explosives creates no liability. ${ }^{41}$ Even where a city neglected to enforce an ordinance regarding the roaming at large of swine in the streets, which established a penalty and also made provision for impounding such animals, and as a result of this nonfeasance a child was killed by wandering swine, it was held that the city was not liable. ${ }^{42}$

The doctrine of respondeat superior does not hold good generally for municipal corporations. It is applied merely in respect to corporate functions, and even in this application a very strict construction is given to it.

As a result of all these distinctions, municipalities largely escape liability for tort. There are several factors, however, which tend to increase the tort liability of municipal corporations. The first is the fact that state legislatures are more and more imposing liability for injuries caused by certain types of acts, such as: Careless driving, resulting in injuries to children who are being transported to school; mob violence; injuries inflicted upon domestic animals by dogs; negligent operation of motor vehicles by firemen and policemen.

Another factor undoubtedly making for an extension of liability is the increased recognition by the courts that the once generally accepted distinction between the public and private functions of a governmental unit is unjust and absurd. Thus, in the case of Fowler v. City of Cleveland, ${ }^{43}$ Judge Johnson attacked that "vague and uncertain sphere of what is called a governmental function," and likened a modern city to a great public service corporation. The Supreme Court of South Carolina has described the doctrine of public and governmental functions as a "maze of

\footnotetext{
${ }^{39}$ Tooke, The Extension of Municipal Liability in Tort (1932) I9 VA. L. Rev. 100-10x.

10 See Birmingham v. Carle, 191 Ala. 539, 68 So. 22 (1915).

11 Zywicki v. Joseph R. Foard Co., 206 Fed. 975 (D. Ct. D. Md. 1913).

12 Levy v. Mayor, I Sandf. 465 (Super. Ct. N. Y. 1848 ).

${ }^{43}$ I00 Ohio St. 158, 126 N. E. 72 (I919).
} 
shadowy distinctions." 44 The Supreme Court of Florida has decided that a city under a commission form of government is subject to the same rules of tort liability as a private corporation would be. ${ }^{45}$

\section{Liability of quasi-corporations.}

Included within the field of so-called quasi-corporations of a public nature are counties, townships, school districts, road districts, and so forth. With minor exceptions which are provided for by statute, counties are not generally responsible for the torts of their agents. This immunity appears to be a direct legal heritage from English common law. In the English case of Russell and Others v. The Men of Devon, ${ }^{46}$ it was held that an unincorporated county was not responsible for injury caused to an individual by a defective bridge, because damages could not be recovered against the inhabitants of the county in their individual capacity, and "there is no corporation fund out of which satisfaction is to be made." In the American case of Mower v. Leicester, ${ }^{47}$ which became a leading case on the subject, the Massachusetts court, following the reasoning of Russell v. Men of Devon, applied it to the town of Leicester and added: "Corporations created for their own benefit stand on the same ground, in this respect, as individuals. But quasi corporations, created by the legislature for purposes of public policy, are subject, by the common law, to an indictment for the neglect of duties enjoined on them; but are not liable to an action for such neglect, unless the action be given by some statute." As the attorney for the plaintiff in this case pointed out, none of the reasons which prevailed in Russell v. Men of Devon case were logically applicable, since here the town was a corporation capable of suing and being sued. Here the town was expressly bound by statute to keep the road in repair, whereas the county of Devon was not so bound. In Russell v. Men of Devon case there was no treasury from which judgments could be recovered; here there was. It is altogether probable that the Massachusetts court was influenced by the dictum of Russell v. Men of Devon case: "If this experiment had succeeded, it would have been productive of an infinity of actions."

Other reasons have been given for the immunity of the county from tort liability, such as: That the county is an arm of the state for carrying out state purposes; and that counties and so-called quasi corporations are as a rule involuntary political divisions of the state, organized without the consent of their inhabitants, whereas municipal corporations are voluntary associations. ${ }^{48}$

In some states the county has been organized as a "municipal" corporation, with power to sue and be sued, and the statutes have made it specifically liable for such things as highways, bridges, and public buildings. Yet on the ground that these statutes are in derogation of the common law, the courts have given them a very narrow construction.

\footnotetext{
"Irvine v. Greenwood, 89 S. C. 5 II, 72 S. E. 228 (IgII).

¿Eaufman v. Tallahassee, 84 Fla. 634,94 So. 697 (I922).

${ }^{10}$ T. R. 667, Io Eng. Rep. 359 (K. B. I788).

47 Mass. 247, 250 (1812).

${ }^{18}$ See Borchard, Government Liability in Tort (1924) 34 YArE L. J. I, 42-43.
} 
Despite the general doctrine to the contrary, there are a number of instances where the courts have held quasi-corporations liable in tort. Thus a New York court held that a town with statutory power to establish parks should be liable when a death was caused by the dangerous condition of a bathing beach maintained in connection with the park. ${ }^{49}$ At times townships or New England towns have been held liable for torts which have occurred in connection with undertakings conducted partly for profit. ${ }^{50}$

\section{Responsibility of officers.}

Although several specific differences exist in respect to the liability of officers in the various political divisions of the United States, the underlying principles are much the same.

The first question that must be asked in respect to the tort liability of an officer is: Whether he is exercising a legislative, a judicial, a quasi-judicial, an executive, or an administrative function.

x. Legislative officers. It is generally held that legislative officers are not liable to civil actions for legislative acts, on the ground that they are called upon to exercise judgment and discretion as to the needs and welfare of the public, and that their duties are owed to the public at large and not to individuals. "Discretionary power is, in its nature, independent: to make those who wield it liable to be called to account by some other authority is to take away discretion and destroy independence."51 This freedom from liability is true not only for legislative bodies proper, but also for inferior legislative or quasi-legislative bodies such as municipal councils, county commissioners, boards of supervisors, etc. It seems to be the character of the duty laid upon such officers, and not the name of the officer, which controls liability. ${ }^{62}$

2. Judicial officers. No civil action can be brought against judicial officers for the recovery of damages, when such officers are acting within their jurisdiction. The reasons given are:

a. If such action could be maintained, the protection essential to judicial independence would be entirely swept away. ${ }^{\mathbf{5 3}}$

b. If a judge could be sued, his time and energy would be consumed.

c. If a judge, placed in a position of defense as a wrongdoer, were found guilty, this fact would weaken the weight of his subsequent decisions.

d. Civil responsibility would make for dishonest judgments.

e. Such action would multiply litigation and open up each case to endless controversy. ${ }^{54}$

3. Executive officers. In the United States, contrary to the English theory, a distinction is made between the liability of high executive officers, such as the President

${ }^{49}$ Augustine v. Town of Brant, 249 N. Y, 198, 163 N. E. 732 (1928).

${ }^{50}$ Moulton v. Scarborough, 71 Me. 267 (1880). ${ }^{61}$ Cooley, Tonts (2d ed. I888) 443.

52 Mechem, A Treatise on the Law of Public Offices and Officers (1890) $\$ 646$.

${ }^{3}$ Bradley v. Fisher, 13 Wall. 335,348 (U. S. 1871 ).

"See Bradley v. Fisher, supra note 53; MEcheM, op. cit. supra note 52, $\$ \$ 619$ et seq., CooleY, Torts (2d ed. 1888) 475 et seq. 
of the United States, the state governors, federal cabinet offcers, and heads of independent establishments and offices, and the liability of administrative officers of a lower rank. The courts of the United States have held in several cases that these higher officers are not liable to mandamus..$^{55}$ Commentators have usually held that since this is so they are also not liable for damages when they are acting within their authority and are carrying out functions bestowed upon them by law. The reason usually given for this freedom from responsibility. is the necessity for the exercise of a wide discretion, with which the courts will not interfere. Another reason advanced is that of the almost sovereign prerogative power of the chief executive officers of nation and state. ${ }^{58}$ Finally, the doctrine of the separation of powers is sometimes given as a reason why the courts will not subject chief executive officers to liability. ${ }^{57}$

Immunity from damage suits also seems to be extended to heads of departments and independent establishments. Since the duties of mayors are not regarded as involving sovereign functions, and since the doctrine of separation of powers does not seem applicable, they are not exempt from damage suits.

The liability of ministerial officers, as distinguished from executive officers, appears to be the same for all divisions of government. The first principle to be considered in respect to their responsibility is based upon the distinction between duty to the public and duty toward an individual. In case the duty is to the public alone, the liability is to the public alone, and the remedy is by public prosecution. ${ }^{58}$ The state may bring a criminal action against the officer for failure to discharge some duty with the performance of which he is charged by statute, when by the same or another statute its non-performance is made a criminal offense. ${ }^{59}$ But to sustain an action by a private individual against a public offcer, it must be shown that the duty violated was a duty to the individual. ${ }^{00}$

Besides criteria derived from the nature of the officer, other important criteria have been developed. The most important of these consider: Whether the officer had legal power to act; whether the law under which he acted was constitutional; whether the officer was required to know the law; whether or not he had exceeded his jurisdiction; whether the action was one of misfeasance or of non-feasance; whether the act was done under the orders of a superior; whether the officer acted arbitrarily, maliciously, or wilfully; and whether the duty was ministerial or discretionary.

In general, an officer is not liable for acts done under the authority of or the color

${ }^{5}$ Marbury v. Madison, I Cranch 137, I70 (U. S. I803); Decatur v. Paulding, I4 Peters 497 (U. S. 1840); Kendall v. U. S., 12 Peters 524 (U. S. I838); Butterworth v. U. S., II2 U. S. 50 (1884); Hatfield v. Graham, 73 W. Va. 759,81 S. E. 533 (19r4); Moyer v. Peabody, 212 U. S. 78 (1909).

${ }^{50}$ See cases cited supra note 55 .

${ }^{67}$ See particularly Hatfield v. Graham, supra note 55.

cB "The rule of official responsibility, then, appears to be this: That if the duty which the official authority imposes upon an officer is a duty to the public, a failure to perform it, or an inadequate or erroneous performance, must be a public, not an individual injury and must be redressed, if at all, in some form of public prosecution." Coolex, ToRTs (2d ed. I888) 446.

${ }^{50}$ State v. Godwin, 123 N. C. 697,3 I S. E. 221 (1898); Lamar Pub. Co. v. Hoag, 54 Colo. 542, 13I Pac. 400 (1913).

${ }^{\circ 0}$ Mechem, op. cit. supra note 52, 5600 ; see Lamar Pub. Co. v. Hoag, supra note 59. 
of law. In the case of Den ex dem. Murray $v$. Hoboken Land and Improvement Co., ${ }^{61}$ it was held that a public agent cannot be made responsible for obeying the lawful command of the government. Nor will a public officer be held personally responsible for damages unless it is clearly proved that he acted in violation of law, arbitrarily, and without regard to the functions with which he is entrusted. ${ }^{62}$ Nor are officers answerable for consequential damages, if they act within their jurisdiction, and with the requisite care and skill. ${ }^{63}$

The general rule that the carrying on of his functions under legal authorization will protect the officer, has one very important exception. This is in respect to unconstitutional laws. The argument goes on the ground that an unconstitutional law is no law at all, ${ }^{64}$ and therefore the officer who acts under it acts not as an officer but as a private man. Professor Oliver P. Field ${ }^{65}$ thus sums up the liability of officers under such "laws":

I. Officers are liable for refusal to act if the statute authorizing them to act turns out to be constitutional and if some private individual has been injured thereby.

2. Officers are liable for taxes collected under invalid statutes if they were paid under protest and their payment was involuntary. The fact that the officer has paid money into the state treasury will not be a defense to such an action.

3. There is a conflict of authority as to whether an officer is liable for the destruction or invasion of property under an unconstitutional statute.

4. Officers are liable for interference with personal liberty if such interference is justified solely on the ground of an invalid statute.

5. Officers are not liable for making complaints under invalid statutes.

6. The weight of authority holds that magistrates are not liable for issuance of process or committing a person under an unconstitutional law, but a few cases impose liability.

7. Officers executing process under an unconstitutional statute are held liable in some states but not in others, although the tendency seems to be to exempt them and to treat them as executing "fair process."

It is nearly always held that ultra vires acts, constituting malfeasance, create personal liability of officers. ${ }^{60}$ Officers are liable for acts in excess of their jurisdiction, not only to individuals, but to the government as well. ${ }^{67}$

In several cases the courts have held that when an officer, although operating within the general sphere of his jurisdiction, makes a mistake in fact, such as a wrong diagnosis, he is personally liable. Thus, in Miller v. Horton, ${ }^{68}$ where a horse

ox 18 Howard 272, 283 (U. S. 1855 ).

62 Boutte-v. Emmer, 43 La. Ann. 980, 9 So. 921 (I89r).

${ }^{63}$ Eslava v. Jones, 83 Ala. 139, 3 So. 317 (1887); MecheMs, op. cit. supra note 52, 3675.

64 Norton v. Shelby County, x 8 U. S. 425, 442 (I886), when Justice Field said: "An unconstitutional act is not a law; it confers no rights; it imposes no duties; it affords no protection; it creates no office; it is, in legal contemplation, as inoperative as though it had never been passed."

${ }^{\circ 0}$ The EFFect of AN UNconstitumonal StatuTe (1935) $745-46$, by permission of the publisher, The University of Minnesota Press, Minneapolis, Minn.

${ }^{\circ 0}$ Barnes v. The Railroads, 17 Wall. 294, 307 (U. S. 1872); Mock v. Santa Rosa, 126 Cal. 330, 58 Pac. 826 (r899); Bolton v. Vellinez, 94 Va. 393, 26 S. E. 847 (1897); Burch v. Hardwiche, 30 Gratt. 24 (Va. 1878 ).

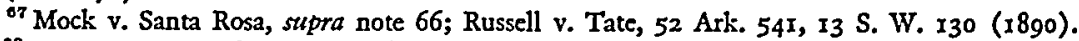

${ }^{68} 152$ Mass. 520, 26 N. E. 100 (189I). 
was killed by a board of health on the ground that it had glanders, and later a jury decided that as a matter of fact it did not have glanders, the court held: That since the officers had only jurisdiction to kill animals actually so affected, but did not have jurisdiction otherwise, they had acted ultra vires and so were liable. ${ }^{69}$ This may be called the "jurisdictional fact" doctrine.

Mere omission to discharge an official duty does not, as a rule, create personal liability of the officer. However, if the officer refuses to perform a duty, without which action a just claim against the public cannot be paid, he is personally liable to the claimant to the extent to which he has caused the injury. Where the duty that the officer refuses to perform is to the public alone and not to an individual, redress must be sought by public prosecution. Where a duty is a positive one provided for by law, the general rule is that the officer will be liable if he discharges it in a negligent, wrongful, malicious, or corrupt manner, or if he refuses to perform it. ${ }^{\mathbf{7 0}}$

In respect to the responsibility of superior officers for acts of those under them, there is a general rule to the effect that superiors are not liable for the acts of their subordinates, even when the latter are employees rather than officers. ${ }^{71}$ There are, however, exceptions to this rule. ${ }^{72}$

\section{Summary}

The system of tort responsibility in the United States is based upon a great variety of distinctions. Running through the whole system is the distinction between sovereign and non-sovereign acts. This is seen in respect to responsibility for acts of national, state, county, and even municipal governments, since the distinction between public and private acts rests ultimately upon a similar basis. It also appears in respect to the responsibility of the President of the United States, cabinet officers, high boards and commissions, and state governors.

Distinctions are also found as to the tort liability of various divisions and subdivisions of government. The rules governing responsibility are very different for the respective units. The state and national governments are not, as a rule, responsible for tort, since their sovereign nature is interpreted as meaning that they cannot be sued without their consent. Counties and quasi-municipal corporations, when

${ }^{\circ 0}$ See also Pearson v. Zehr, I38 Ill. 48, 29 N. E. 854 (I89r); People ex rel. Copcutt v. Board of Health, 140 N. Y. I, 35 N. E. 320 (1893).

${ }^{70}$ Fitzpatric v. Slocum, 89 N. Y. 358 (Ct. App. I882); Mott v. Hull, 5I Okla. 602, I52 Pac. 92 (1915); Lamar Pub. Co. v. Hoag, 54 Colo. 542, I3I Pac. 400 (1913); Hupe v. Sommer, 88 Kan. 56r, 129 Pac. 136 (I9r3).

${ }_{71}$ Bowden v. Derby, 97 Me. 536, 55 Atl. 417 (1903); Keenan v. Southworth, 110 Mass. 474 (1872); Bankers' Mut. Casualty Co. v. Minneapolis, St. Paul etc. Ry., II7 Fed. 434 (C. C. A. 8th, 1902); Walsh v. Trustees of N. Y. etc. Bridge, 96 N. Y. 427 (I884); County Commissioners v. Duvall, 54 Md. 350 (1880); Robertson v. Sichel, 127 U. S. 507 (1888).

${ }^{72}$ Mechem states them as follows: "Thus the superior officer will be liable, (I) where, being charged with the duty of employing or retaining his subordinates, he negligently or willfully employs or retains unfit or improper persons; or, (2) where, being charged with the duty to see that they are appointed or qualified in a proper manner, he negligently or willfully fails to require of them the due conformity to the prescribed regulations; or (3) where he so carelessly or negligently oversees, conducts or carries on the business of his office as to furnish the opportunity for the default; or (4) and a fortiori, where he has directed, authorized or cooperated in the wrong." Op. cit. supra note $52, \$ 790$. 
carrying out state functions, are considered as arms of the state and are covered to a large extent by the cloak of sovereignty. In various other connections they have been held liable in tort.

In respect to the responsibility of a municipal corporation, the chief distinctions made seem to be those between its acts in a public capacity and its acts in a private capacity. When a municipal corporation is carrying on its public functions, as a general rule it is irresponsible. When acting in a proprietary capacity, it is responsible.

Another distinction, made in respect to both municipal corporations and officers, is that between nonfeasance and malfeasance. Responsibility, as a rule, does not exist for the former, but does for the latter.

The responsibility of officers is controlled by a multitude of distinctions. The chief of these are: (r) The distinction between legislative, judicial, and quasi-judicial acts; (2) the distinction between higher executive officers and administrative officers; (3) the distinction between misfeasance and nonfeasance; (4) that between ministerial and discretionary acts; $(5)$ that between a public duty and a duty toward an individual; (6) that between legal and ultra vires acts; (7) the distinction between operating under a constitutional act or an unconstitutional act; (8) the distinction beween mere omission to discharge a general official duty and failure to discharge a positive duty; (9) the distinction in respect to responsibility or non-responsibility for acts of subordinates; and (ro) a large number of minor distinctions.

The net result of the American system is, on the whole, to protect the government and the officers of government against tort liability. In fact, so encumbered is the American system of responsibility with metaphysical and legal distinctions, that it becomes easy for the courts to deny responsibility where to the average person it would seem clear.

\section{The German System ${ }^{73}$}

The responsibility of the state and its agents in Germany has developed under the influence of two principal sets of legal ideas: ( $I$ ) that of the Roman law, and (2) that of the old Germanic law. ${ }^{74}$ According to Roman law, a distinction was made (as it is in American municipal law) between the acts of the city in its private capacity, and those in its public capacity. In its private relationships, the city was liable as a private individual would be. It was not, however, responsible in general for damages caused to third persons because of illegal conduct on the part of public organs and officers. If the persons who were acting for the city were its slaves, or had been appointed as its agents or administrators, the doctrine of the ordinary law in respect to master and servant applied. ${ }^{75}$

\footnotetext{
${ }^{73}$ It is quite impossible to find out what the actual situation is in Germany today in respect to the responsibility of the state and its agents, due to the general lack of correspondence between law and practice which exists under the Nazi system. The form of the old system of law remains, although actual practice may be very different. This study, then, must confine itself to the legal and theoretical basis of the German system rather than its present operation.

${ }^{74}$ See Stern, Die Haftung des Staates Für seine Beamten und ANGestelltien, etc. (1928).

${ }^{75}$ Loening, Die Haftung des Staates aus Rechswdigigen Handlungen seiner Beamten nach deutschem Privat- und Stantsrecht (x879), 23-24; see also Fromberg, Die Haftung des Fiskus fün SEINE VERTRETER (I908) 3-I0.
} 
When a city (and later a state) officer exercised the rights and carried out the duties belonging to the commonwealth, only the officer and not the commonwealth was liable for injury caused to third persons for illegal action. The one injured could bring a complaint against the culpable officer, but not against a state or the municipality. ${ }^{76}$

In the later imperial period, the theory developed that holding the officer alone responsible was not just to the injured party; since, especially in the case of a lower officer, the damage might be entirely beyond his capacity to make redress. Although this idea, if developed logically, would lead to the conception of state responsibility, such development did not take place. Instead, higher officers were required to assume responsibility for errors in official duty that were made by officers subordinate to them. Despite this theoretical situation, such responsibility was made effective in practice, as a rule, only if the higher officer himself had been guilty of misfeasance or nonfeasance. This was not always true in individual cases; and occasionally the superior officer was held responsible even when he himself had been guilty of no lapse of official duty. ${ }^{\mathbf{7 7}}$

The Roman law also made a sharp distinction between the personality of the individual members of the community, and the totality of those members organized into a body corporate. A complete separation was made between the legal relationships of the organized group and those of individual members. "The rights and duties of the state, the cities, and the corporations, were not the rights and duties of the individuals, who were no more responsible for the faults of the unity than this unity was responsible for the faults of the individuals."78

Only when acting within their legal powers, were the officers constituting the organs of the incorporated body acting for it. If they exceeded those powers, or violated laws in exercising them, they acted as private individuals. Since it has no official authority to perform illegal acts, no illegal act could be chargeable to the corporate body, which was considered as incapable of an illegal purpose. The principle was thus developed, that the corporate body could not be required to compensate individuals for injuries caused by the illegal acts of its agents. This is much the same as the English theory. ${ }^{79}$

The medieval theory of Germany was quite different. "The corporation, of which the individual was a member, did not merely demand particular functions from the individual and guarantee to him particular rights, but rather involved his entire personality, which in state and church, in commune and realm, in his occupation and in society as a whole, was considered as only a member of the organization. The corporation did not stand opposed to the individual as something different, but rather the individual lived only as a member of the corporation, just as the corporation

\footnotetext{
${ }^{76}$ I MoMmsen, Römisches StaAtsrecht ( 1887 ) 673; Mommsen, Abriss des Römischen StantsRECHTS (I907) I35-36.

${ }^{77}$ LOENING, op. cit. supra note 75, at 25 . $\quad{ }^{88} I d .26$.

${ }^{79}$ Since the King would not have allowed or ordered a wrong to be done, if wrong is done, it must of necessity be due to the wrongful act of an officer. Tobin v. Regina (I864) 33 L. J. C. P. I99, I6 C. B. N. S. 3 Io.
} 
lived only in its members. The corporation, which was identified with the totality of its members, had therefore the obligation, in case of necessity, to undertake the obli. gations of all the individuals, just as the individual had the duty to undertake all the obligations of the corporation." 80

During a rather long period when this general attitude prevailed, there was not, and could not well be, a definite line between private and public law. Throughout the Middle Ages, the legal view prevailed that in the case of the fault or obligation of an association, the creditor, in extreme cases, might bring suit against the members of the association. To a certain extent, also, acts of individual members were considered to be acts of the corporation which the members represented. When the organs of the corporation, acting in the name of the corporation, made declarations of will and performed acts, they acted not only for the corporation as a whole, but also for all of the individuals associated in the corporation. Their will and acts were deemed to be the will and the acts of all the individuals. ${ }^{81}$

From this there quite logically followed the doctrine that the corporation itself could perform illegal acts, and that any injury caused to the rights of individuals by illegal acts of the corporate organs or officers could be attributed to the corporation. Although it was realized that the corporation, as such, could not act, the law as interpreted meant that the totality of the members must answer for the acts of the organs. As a result, the corporation might be declared responsible to compensate for injuries resulting from the illegal acts of its organs; and penalties might also be laid upon it. ${ }^{82}$

This point of view gradually changed in important respects, as municipal and other corporations began to extend their services and it became necessary for them to employ many subordinate administrative officers. The distinction was then made between organs which were the representatives of the corporation, and officers employed in other capacities. The theory developed, that the acts of mere administrative or ministerial officers should not be placed upon the same basis as acts performed by representative or policy-determining bodies, or directorates. As a result of the study of Roman law, there also grew up a changing view of the relationship of the individual to the association or corporation. The individual member was no longer equivalent to the corporation as a whole. The corporation began to refuse to assume responsibility for the acts of its members, even when such acts were performed in the name of the corporation.

As Roman law took possession of the minds of German lawyers, many doubts developed regarding the German philosophy of the Middle Ages. The old medieval conceptions of the corporative state were gradually supplanted by the Roman ideas.

Toward the end of the seventeenth century, largely under the influence of Niko-

\footnotetext{
so 2 Gierke, DAs deutsche Genossenschaftsrecht (1873) 385-86; see also I Grerke, Deutsches Pruvatrecht (1895), $\$ \S 68,75,76$.

${ }^{81}$ LOENING, op. cit. supra note $75,26-28$.

${ }^{82}$ Gierke, op. cit., vol. 2, 522, 817, 905; see also MAUrer, Geschichte der Markenverfassuno $(1856)$ I93.
} 
laus Hert, ${ }^{83}$ the ruling opinion developed that the superior should be held responsible only when the officer had acted within the limits of his office, or of the functions bestowed upon him. It was argued that since the officer is not actually the agent of the superior, but an organ of the public power, the relationship should be recognized as a public one to which the private law doctrine of master and servant or principal and agent does not properly apply. These new ways of viewing the problem somewhat checked the theory that the commonwealth should be responsible as of right for the illegal acts of its organs, but did not overcome it.

After the middle of the eighteenth century the theory of the responsibility of the "fiscus" began to develop. The word fiscus was (and still is) used both for the public treasury and for any unit of government when carrying on purely business affairs, especially when dealing with private persons. One cannot do business, it was held, with a unit of government acting in its capacity as possessor and user of some portion of sovereign power; but one can deal with, and sometimes bring suit against, a unit of government acting in its proprietary capacity, or its capacity as fiscus. The distinction between sovereign acts and fiscal acts was comparable to our distinction in the law of municipal corporations between public acts and proprietary acts. The tendency developed of making the fiscus the "whipping boy of the state." Several German states established laws providing for the responsibility of the fiscus, and others made the members of the superior financial authority jointly responsible. ${ }^{84}$

After the middle of the eighteenth century, some courts began to declare that the acts of a superior officer, performed in the exercise of his official power, were binding upon the public corporation whose officer he was; that the principles applicable to a private agent could not be applied in all cases to a subordinate officer who was under oath and subject to special obligations of a public law character; but that the superior might be held liable for allowing the acts of his subordinate. ${ }^{85}$

After the latter part of the eighteenth century, the question of responsibility for tort in Germany was gradually removed from the realm of mere court decision and was placed under the control of statutory and constitutional law.

The General State Code of Prussia, ${ }^{86}$ which was adopted during the last decade of the eighteenth century, lays responsibility upon officers except in respect to the fiscus by providing:

"One who accepts an office must apply all requisite diligence to fulfilling the obligations thereof according to his duty. Any injury which may occur in this connection, which could and should have been prevented by proper care, and according to the knowledge requisite for the administration of the office, he must make good.

${ }^{83}$ I Hert, De Plumubus Hominibus Personam unam Sustinentibus (i709) tome 3, 27 et seq., especially at $44, \$ 6$ and vol. 2 , tome $3,4 \mathrm{I}$ et seg.

" Hatschek, Lehrbuch des Deutschen und Preussischen Verwaltungsrechts (7th, 8th ed., I93I), 3. I Mayer, Deutsches VerwaltungsRecht (3d ed., I924) I89 et seq.; Fromberg, op. cit. supra note 75,21 et seq.

85 Pfeiffer, Praktische Ausführungen aus Allen Theilen der Rechtswissenschaft (i828) 376 , in discussing court decisions of 1762 and 1763 .

${ }^{80}$ Allgemeines Landrechr für die Preussischen Staaten, of June 1 , I794; still in effect although extensively amended (hereinafter referred to by its traditional abbreviation "A. L. R."). 
Superior officers who, by proper supervision, could have prevented the injuries caused by the official acts of their subordinates, are responsible for the damages arising from their negligence, to the state as well as to the private individuals who suffer therefrom." "87

"In the use, the enjoyment and the administration of its domains and property, the state, as a rule, stands in relation to the law on the same basis as any private proprietor."88

The germ of a broad ethical conception of the distribution of the social burden is found in the following passage:

"Individual rights and privileges of the members of the state must yield to the right and duty of furthering the general welfare, when there is an actual contradiction or collision between the two. However, the state is required to compensate anyone from whom his special rights and privileges have had to be withdrawn for the benefit of the community." 89

From $I 820$ to $I 824$, the Superior Court of Appeals of Cassel rendered several decisions to the effect that "the state is responsible for the official acts of all of its servants who are entrusted with a part of state sovereignty, and should compensate persons injured by such servants when exercising sovereign powers."90 Jurists in Germany after this time began to make distinctions between public law and private law as regards responsibility. Sundheim ${ }^{91}$ observed that the duty of making compensation by the state for illegal acts done by officers in the exercise of sovereign power was not founded entirely upon the basic principles of the private law, and therefore could not be decided by such principles. The basis of state liability, he held, is in reality the fact that the state has placed its officers in such a relationship to its citizens as to make it possible for the former to apply state powers and functions unjustly against the latter.

Pfeiffer, in his Praktische Ausführungen aus Allen Theilen der Rechtswissenschaft, further developed the idea that the relationship of the officers to the state is one of public and not private law. He held that the state must be responsible for acts of sovereign power, since the citizen is not, as in the case of contracts, able to deal or not to deal with the state as he wishes but is forced to deal with it and cannot refuse obedience.

Zachariae $^{92}$ maintained that no distinction should be made between judicial and administrative officers; that the state should be responsible only when officers have acted within their official sphere; that a distinction should be made between those cases in which private affairs are carried on between the state and individuals by the

${ }^{87}$ A. L. R. II, tit. xo, $\$ \$ 88-90$.

${ }^{88}$ Id. tit. $14, \$ 76$.

${ }^{89}$ A. L. R. Einleitung (Introduction), 74-75. For the same principle, see pt. I, tit. 8, \$\$29-31.

${ }^{90}$ Erkenntnisse of March 25, 1820, March 7, 1823, April 7, 1824; cited in 3 PFeIfper, op. cit. supra note $85,377-384$.

${ }_{91}$ PRAKTISCHE RECHTSFRAGEN (1827) pt. I, Über Schadensstiftung durch Staatsbeamten und Haftverbindlichkeit des Staates dafür, 4 et seq.

${ }^{22}$ Über die Haftverbindlichkeit des Staates aus rechtswidrigen Handlungen und Unterlassungen seiner Beamten (I863) I9 ZTSCHR. F. D. GEs. StaAtswiss., 582-652. 
properly authorized officers, and those in which there is an exercise of public authority upon persons subject thereto; that in respect to undertakings of a private legal nature made by representatives of the state, the ruling principles of the civil law are decisive; that when exercising the sovereign compulsory power, the state should be responsible only in a secondary capacity, in case the injured person is unable to secure his rights from the officer at fault. This liability of the state rests upon its guarantee of the rightful actions of officers-a guarantee based upon principles of public law rather than private law.

The prevailing judicial doctrine of the nineteenth and early twentieth centuries was well summarized by a decision of the Reichsgericht in $1909,{ }^{93}$ in which the court said in part:

According to the continuous line of decisions of the Reichsgericht ... in respect to the liability of the Prussian State for damages arising from injuries caused by its officers, a distinction must be made between the fiscal rights and the sovereign rights of the state. Concerning the exercise of the fiscal rights, as in the administration of state property or the protection of rights flowing out of contractual and other private legal relationships ... the state as a juristic person is responsible for the faults of volition of its organs which cause damage to others, just as a natural person is responsible for his own injurious acts. On the other hand, the state is not liable for the injuries which occur in connection with the exercise of its sovereign rights ... through the actions of its officers, in the absence of an express legislative provision establishing such liability in special instances. In the still valid Cabinet Order of December 4, I83I, respecting the exact observation of the boundary between state sovereign and fiscal legal relationships, it is expressly declared that it would be a mistake to hold, that out of the results and operations of a sovereign legal act, the injured person might acquire a claim for compensation against state property. ${ }^{94}$

The Civil Code for the Reich, which went into effect on January $\mathrm{I}$, $\mathrm{xg}$,oo, is of profound significance as regards the responsibility of the state and its officers. It is true that the Code did not directly regulate the liability of the Reich or the member states for wrongful acts of offcers exercising the sovereign power. It did, however, greatly clarify the law in respect to responsibility in fiscal matters, it established the general principles of the responsibility of officers, and it set forth the conditions under which they should be responsible.

About this time a number of state laws, including that of Prussia, required the state or the appropriate subdivision to assume the liability of the officer in case of violation of his official duty. Others made the state or its subdivisions liable in only a secondary way, as a guarantor when the officer was unable to make compensation. A few states did not establish any general principles of liability, but enacted special laws regulating liability for particular injuries or under exceptional circumstances.

${ }^{03} 7$ I Entscheidungen des Reichsgericht in Zivilsachen (hereinafter referred to by the usual abbreviation "R. G. Z.") $44,46$.

"This cabinet order reads in part as follows:

"What belongs to the sovereign rights of the supreme head of the state, and what is to be understood by the fiscus, is set forth .... in the State Code. A complaint based on private law against an act of sovereign power is not admissible, even though it is argued that a claim arising from the consequences and applications of this act should be permitted, not against the person of the sovereign, but against the state treasury." I Gesetz-Sanimiung für die Kön. Preussischen Stanten, 285. 
Many of the doctrines regarding responsibility, that had been developed by writers and theorists, were finally embodied in the Constitution of August II, 1919. Article I3I of this Constitution provides:

"If an officer, in exercising the public authority entrusted to him, violates his offcial obligation toward a third party, the responsibility is borne fundamentally by the state or the public body in the service of which the officer stands. The right of reimbursement in respect to the officer is reserved. Access to courts of general jurisdiction . may not be precluded. More detailed regulation is a function of the legislative body concerned."

This Article accomplishes five principal things: (I) it establishes a unified basis for responsibility, which is applicable to all divisions of government and all public corporations or associations; (2) it makes the state or public body liable for injuries caused to third persons, by its officer who acts in violation of his official duty when exercising the public power; (3) it reserves the right of reimbursement against the officer to the state or public body which has made compensation for the injury; (4) it provides that suit may be brought before the regular judicial courts, by procedures and remedies which are provided for litigants in any civil suit; (5) it permits the legislative body concerned to make more detailed regulations. The Article does not, however, deal with activities of officers who are representing governmental bodies in their civil capacity, or as fiscus.

Almost immediately after the adoption of the National Constitution, questions arose as to the relationship between its Article ${ }^{3} 3 \mathrm{I}$ and the national liability law, and between this Article and the state liability laws. Because of spatial limitations, only a few of these questions can be discussed here.

One of the most important was: whether Article $13 \mathrm{r}$ contained directly and immediately applicable law, or whether it merely set forth guiding principles. The Reichsgericht, in a decision of $192 \mathrm{I},{ }^{95}$ said: "A present, immediate (that is, selfexecuting) provision is established, which requires no further law to make it applicable, or to provide for its execution." It held that one reason why this Article had been adopted as directly applicable law was the wish to prevent each individual state from deciding "whether and when it would make the guiding principles of state responsibility effective for its territory," and to establish responsibility "as an immediate fundamental right of all Germans, for the whole domain of the Reich."

The same court has held that other liability laws are not only repealed in so far as they are contrary to the National Constitution, but are also largely superseded even when they are in agreement with it, sunce now only the provisions of Article I3I of the Constitution are authoritative law for the question of responsibility itself.

The Reichsgericht has held that the responsibility established by Article I3I extends to all public corporations. ${ }^{97}$ Consequently, an organization such as the National Insurance Institute is responsible for violations of official duty committed by its officers in the exercise of public power.

${ }^{95}$ 102 R. G. Z. 166, 168, I7I (1921).

${ }^{98}$ Id. at 170 .

${ }^{97}$ II2 R. G. Z. 335,337 (I926). 
The question was raised as to the relationship of Article I3I $^{\mathrm{I}}$ of the Constitution to Article 839 of the Civil Code, which establishes the nature of official responsibility. On this point the court held that Article I3I can mean nothing else "than the responsibility as it is laid upon the officer by Article 839 of the Civil Code; therefore only in case of intentional or negligent breach of official duty, and only under the limits of paragraph $x$, sentence 2 , (subsidiary) ${ }^{98}$ of paragraph $2^{99} \ldots$ and of paragraph $3^{100}$ ... of Article 839." It can readily be seen, therefore, how closely bound up is the responsibility established under Article $13 \mathrm{r}$ of the Constitution, with the responsibility of officers established by the Civil Code.

Article $13^{101}$ of the Constitution makes a fundamental distinction between acts of public power and private acts. This Article, like Section 839 of the Civil Code, has to do only with public or sovereign acts of the nation, state or other public corporation. It does not affect these governmental units in so far as they are carrying on merely private or fiscal acts. For all private acts, where the Reich or any of its subdivisions acts as a fiscus, proprietor, or entrepreneur, provisions of Sections $3 \mathrm{I}$ and 89 of the Civil Code govern, rather than Article I3I of the Constitution.

An important decision of the Reichsgericht holds that public power is not to be interpreted in a narrow sense, as if it referred exclusively to the exercise of sovereign power. On the contrary, it includes the whole domain of official acts not governed by Sections $3^{\mathrm{I}}$ and 89 of the Civil Code; that is, all official acts which are not devoted to the private legal interest of the Reich or other corporations of public law. ${ }^{102}$

\section{The responsibility of officers.}

The basis of the responsibility of officers must be considered from a twofold viewpoint: responsibility in respect to the exercise of public power, and responsibility in respect to the exercise of fiscal power.

According to Section 839 of the Civil Code, the basis for the responsibility of officers is a wilful or negligent breach of official duty toward a third party; but if only negligence is imputable to the officer, he may be held liable only if the injured

09 This provides: "If only negligence is imputable to the official, he may be held liable only if the injured party is unable to obtain compensation elsewhere."

${ }^{\circ 0}$ Paragraph 2 makes special provisions regarding breaches of official duty in connection with judicial decisions.

${ }^{100}$ Paragraph 3 provides: "The duty to make compensation does not arise if the injured party has wilfully or negligently omitted to obviate the injury by making use of a legal remedy."

${ }^{201}$ See Anschütz, Die Verfassung des Deutschen Reichs (7th ed. 1928) note on Art. 131. The Reichsgericht has said: "If the Reich as law giver, issues commands or prohibitions for the public, it exercises exclusively sovereign power and acts entirely within the domain of public law. For the injurious consequences of the exercise of sovereign power the Reich can be held to answer before the ordinary courts only on the grounds of special provisions of national law, which provide for hearing and trial of claims by the courts of general jurisdiction. For the exercise of sovereign powers by officers, Article I3I of the National Constitution, applying the provisions laid down by Section 839 of the Civil Code, is authoritative. The responsibility for fiscal acts is governed by Sections $3 \mathrm{I}$ and 89 of the Civil Code. Together these two responsibilities are intended to govern the entire domain of state administrative activity, but they have nothing to do with legislative activity." II8 R. G. Z. 326 (I929).

${ }^{103}$ 9x R. G. Z. 273 et seq. (I9I7). This decision, although rendered before the Constitution of I9r9 became effective, sets forth the principles which have governed the application of Article I3I of the Constitution. 
party is unable to obtain compensation elsewhere. This provision now governs the responsibility of officers only in respect to acts of the fiscus. When the officer is carrying out public acts, as we have seen, the responsibility is borne fundamentally by the public body in whose service he works. In carrying out public acts, therefore, so long as the officer remains within his functions, this public body is liable instead of the officer. It is only when, in carrying out public functions, he goes beyond the authority entrusted to him, that he may be sued directly by the individual. Where the state stands responsible for the acts of the officer, however, it has several methods of holding him responsible, such as official discipline, the ordinary penal law, and claims for damages against him.

German jurists believe that there are several important advantages in holding the state rather than the officer responsible to the individual, and in holding the officer responsible to the state rather than to one individual. It prevents the injustice which occurs when the officer alone is responsible to the individual. The officer will not be sentenced to pay damages out of all proportion to his income, nor will the individual receive formal damages which he cannot collect because of the officer's poverty. By holding the officer directly responsible to the state, he will have a direct personal interest in proceeding within the bounds of law, since operation without the bounds of law will subject him to payment of damages to the state, which is far more certain to enforce its rights against him than an individual might be. Finally, it is possible for the state to make the necessary adjustments with its officers, by considering whether the fault was slight but the result grave, whether there were extenuating circumstances, whether or not the officer believed that he was acting within his sphere of duty, and so on, without at the same time injuring the rights of the individual.

\section{Summary}

The basic principles of responsibility in Germany are established by constitutional and statutory law, rather than judicial decisions. The Constitution sets forth these principles where acts of public power are concerned, and the Civil Code states them where private or fiscal acts are concerned.

An important feature of the German system is the fact that basically there is the same system of responsibility for all divisions of government and all public bodies and corporations.

A sharp distinction is made between public law and private law; this is accompanied by a distinction between public or sovereign functions and private legal relationships. The public bodies are responsible directly for injuries caused by the wrongful administration of public and sovereign functions. The individual deeming himself injured does not sue the officer, but sues the public body. The latter, however, retains the constitutional right to sue the officer if it is compelled to make compensation to the injured person.

The responsibility of the state or of its officers is based upon the concept of fault 
or negligence. It is always necessary to find a fault or a negligence before the public body becomes liable.

In respect to liability for public acts, there is no assimilation of the state to a private corporation; that is, the public body is not considered as a private corporation liable for the acts of its employees or agents, but as a public person which assumes responsibility for the acts of its officers.

No distinction is made, as regards responsibility, between governmental units which are sovereign or quasi-sovereign and those which are merely administrative agencies. No responsibility exists, however, in respect to legislative acts.

The German system makes no distinction between officers that are high or low, executive, administrative or judicial. ${ }^{103}$

Finally, suits in respect to torts are brought in the regular civil courts according to the rules of civil procedure.

\section{The French System}

It is impossible to trace in France a continuous development of the system of responsibility for torts. Certain trends, however, are discernible, notably the continuous action of a council of some sort, and the influence of the particular French doctrine of the separation of powers.

During the Middle Ages, officers were often made responsible to the "King's Council" for their conduct in office. This Council, although fundamentally an administrative and advisory body, was given various judicial functions from time to time. By the seventeenth century the Council habitually "evoked," or called before it, suits dealing with administrative matters which had been brought into the courts of justice. This practice enabled the Council to hold a firm hand over administration, but it offered no guarantee to the public that individuals who had been injured by administrative abuses would receive compensation, or any other redress such as they might reasonably hope to obtain in a court of justice. At the time of the Revolution, there was a good deal of agitation for ending the practice of evocation, and for making ministers and other agents of the public authority responsible to the States General for all phases of their official conduct.

The influence of the doctrine of the separation of powers prevailed during the Revolution to such an extent that the judicial courts were denied the right to control administration. At the same time, there was a general desire to see administrative officers controlled and made responsible.

From the time of the Revolution to the present, the development of the theory of the responsibility of the state and its officers falls into three periods.

\section{The first period.}

The first period was from the beginning of the Revolution to the Year VIII (I799I800). During this time a definite theory regarding official responsibility developed. The period shows three main currents of thought, related but rather confused. These

\footnotetext{
${ }^{103}$ As regards judicial officers there is a direct responsibility in respect to property relationships.
} 
were: (I) the theory that officers should be responsible; (2) the conviction that although they should be responsible they should be protected from unjust and malicious suits; and (3) the principle that officers and administrative affairs should be free from interference by the ordinary courts. During this period no systematic theory regarding the nature or extent of responsibility developed.

\section{The second period.}

The second period, which extended from the Year VIII to the decree of September 19, I870, may be called the period of the "administrative guarantee," so far as responsibility is concerned. It was a period in which the responsibility of the state was governed largely by the civil law of responsibility.

Article 75 of the Constitution of the Year VIII had provided: "The agents of the government, other than the ministers, may not be sued for acts relative to therr functions, except by virtue of a decision of the Council of State; in this case, the suit must be brought before the ordinary tribunals." Since at this time the Council of State was primarily an administrative body whose opinions were largely advisory, it is fairly obvious that the administration itself, through this Council, must give its consent before its agents could be sued. The "administrative guarantee," though defended as necessary to efficient government, was naturally unpopular. It was during this period that the so-called civilist school of responsibility developed.

Articles 1382,1383 , and ${ }_{1} 384$ of the Civil Code provided:

"Every action of man whatsoever which occasions injury to another, obliges him through whose fault it happened to make reparation therefor.

"Every one is responsible for the damages which he has caused, not only by his own act, but also by his negligence or by his imprudence.

"A person is responsible not only for the injury which is caused by his own act, but also for that which is caused by the acts of persons for whom he is bound to answer, or by things which he has under his care."

The dominating ideas of these provisions are: that there is responsibility only in case of fault or negligence, and that a principal or master is responsible for his agent. In applying these provisions to the responsibility of the state, the public power was treated as a master responsible for the faults of his agents.

A distinction was made, however, between public acts for which the state would not assume responsibility, and non-sovereign acts or proprietary acts for which it would assume responsibility. The doctrine of agency was applied to the responsibility of the state for acts of its agents that were non-sovereign in character. Sovereign acts were freed from all responsibility.

In 1845 the Council of State, which had not previously been organized by law, was given a statutory basis. ${ }^{104}$ By a law of May $24,1872,{ }^{105}$ it was reorganized as a true administrative tribunal and advisory council. Many later laws have modified its structure or its functions in some ways, but it has retained its status as a special court

${ }^{104}$ Law of July I9, r845, Duvergier, LoIs (1845) 542.

${ }^{105} \mathrm{Id}$. (1872) 213 . 
for administrative cases. The jurisprudence of this court has been one major factor in the development ${ }^{106}$ of modern French administrative law, especially the law of liability, during the third period which will now be discussed.

\section{The third period.}

The third period, which extends roughly from I87o to the present time, may be characterized as the period of the abolition of the "administrative guarantee" and the development of the idea of "personal fault," so far as the officer is concerned; and the period of the development of the public law of responsibility of the state, with its doctrines of fault of service and risk.

By a decree of September I9, I870, the so-called "administrative guarantee" was abolished. ${ }^{\mathbf{1 0 7}}$ For a short time thereafter, it was uncertain whether or not officers could be sued for personal fault before the ordinary courts.

A series of remarkable decisions made by the Tribunal of Conflicts and the Council of State from about 1873 to the present time have developed doctrines concerning both the responsibility of officers and that of the state.

By the celebrated Blanco decision of February $8,1873,108$ following a position taken by the Council of State in the Rothschild decision of $1855,{ }^{109}$ the Council of State established the doctrine "... that the responsibility which may rest upon the state for damages caused to individuals by the acts of persons whom it employs in the public service cannot be governed by the principles which are established in the Civil Code for the relationship of individual with individual; that this responsibility is neither general nor absolute; that it has its special rules which vary according to the needs of the service and the necessity of reconciling the rights of the state with private rights. ...."

This decision definitely did away with the doctrine of state responsibility according to the doctrines of the Civil Code: namely, that there is responsibility only where there is fault or neglect, and that such responsibility is governed by the doctrine of principal and agent or master and servant.

One of the most important of the decisions by the Tribunal of Conflicts, given in the Pelletier case of July $26,1873,110$ established four fundamental principles which, although undergoing a gradual process of evolution, have remained as the basis of the French system of the responsibility of the state and its agents. Those principles may be stated briefly as follows:

I. Since the administrative guarantee is abolished, there is no further need to ask the Council of State for permission to bring suits against officers.

2. The abolition of the administrative guarantee, however, did not do away with the doctrine of the separation of powers; hence, although the regular courts may pass upon the personal faults of officers, they may not pass upon the regularity of administrative acts. Only the administrative jurisdiction may judge such acts.

\footnotetext{
100 The Tribunal of Conflicts has also played an important part in this development.

${ }^{107}$ DUVERGIER, LoIs (1870) 335.

${ }^{200}$ Rec. Cons. d'Et. I $855,707$.

${ }^{108}$ Rec. Cons. d'Et. r873, Supp. I, 6r.

${ }^{110}$ Rec. Cons. d'Ét. 1873 , Supp. I, II8.
} 
3. From this it logically follows that the civil tribunals must declare themselves incompetent when an officer is sued before them for an act relating to his functions, rather than a mere personal act. In case they do not declare themselves incompetent, a conflict arises between the regular court and the Council of State, which must be decided by the Tribunal of Conflicts.

4. Finally, the Pelletier decision firmly established the fundamental distinction between the personal fault of the officer and the fault of service or faulty functioning of the administration itself. This distinction has made it possible to enlarge greatly the responsibility of the state in respect to the wrong or faulty functioning of the governmental services, and to diminish correspondingly the personal responsibility of officers for such fault.

It was necessary at this time, however, to take into consideration the distinction still made between acts of public power (actes d'autorité) and acts of management (actes de gestion) or business acts. For acts of public power, the rule was that the state was not responsible. When, however, mere acts of management were performed in connection with the operation of the public service, the state could be held responsible.

The twentieth century has seen a great change, for by virtue of decisions of the Council of State and the Tribunal of Conflicts, the responsibility of the state has been established for most acts of public power. ${ }^{111}$ Today it may be said that the state is responsible for all administrative acts. No distinction is made as to whether the acts in question involve the carrying on of a so-called sovereign function or a mere proprietary function. The state is quite as responsible for the bad functioning of its military', police, postal, educational, and charitable services, as for its services of a business or proprietary nature, such as the manufacture of tobacco or matches. Only a few of many interesting cases may be given to prove this point.

When a soldier was killed in the course of maneuvers in which blank cartridges should have been used, and medical and other testimony proved that the death was caused by the firing of a bullet from among the troops which participated in the maneuvers, the state was held liable. ${ }^{112}$

When an individual was wounded by a shot fired by a policeman, who mistook him for a criminal, it was held that indemnity should be paid. ${ }^{113}$

A child playing in a school yard bordered with a hedge of thorny bushes fell and lost the sight of an eye because of a thorn. The municipality was held liable, on the ground that thorny bushes constituted a permanent danger. ${ }^{114}$

Beginning with the year 1919, the Council of State has developed another doctrine governing certain types of administrative action: the doctrine of risk. ${ }^{115}$ According

\footnotetext{
${ }^{21 x}$ The exceptions are: (1) parliamentary acts; (2) legislative acts of evcry kind; (3) acts of government (acts of the executive power either (a) in its relationships with Parliament or (b) in international relations); (4) acts connected with the judicial function.

112 Sieur Auxerre, Rec. Cons. d'Et. Feb. 17, 1905, 165.

113 Costa d l'Etat, Rec. Cons. d'Et. Dec. 7, I917, 798.

114 Ville de Toulouse, Nov. 23, r917, Rec. Cons. d'Et. 1917, 760.

115 See Regnault-Desroziers decision of March 28, 1919; see also 3 StrEY, 1919, p. 25, note by Hauriou.
} 
to this doctrine, the state or subdivision may be held liable in a general way because of risks involved in its operations, even though there has been no definite or special fault on its part. In order to establish such liability, it is necessary only to show that an individual has received an injury because of the functioning of a public service.

\section{The responsibility of departments and communes.}

For a great many years the regular courts had jurisdiction over actions in which the responsibility of departments and communes was involved. In this connection the courts made a distinction (such as is made in the United States in respect to municipal corporations) between public acts and private acts, and applied to the departments and communes Article ${ }^{3} 3_{4}$ of the Civil Code regarding the doctrine of agency.

In the Feutry decision of $1908,{ }^{116}$ the Tribunal of Conflicts decided that cases involving the responsibility of departments, communes, and public establishments should come before the Council of State. Thus it brought these subdivisions under the public law doctrine of responsibility based upon fault of service and personal fault, removing them from the application of the old civil law doctrines of subjective fault and of the responsibility of the principal for the acts of his agent.

\section{Responsibility of officers.}

It has been seen that a public officer is liable for personal faults. The question then is: What is a personal fault, and how does it differ from fault of service? Examination of all the cases involving the question of fault of service, decided by the Council of State during nearly half a century, reveals the fact that fault of service is generally (but by no means always) a fault which, though it may be attributable in a certain sense to an agent of the state, is essentially due to failure or mistake in certain mechanical or physical operations in which he is engaged. This is natural, particularly since the motor vehicle has become important in public operations. The injury may be due to failure to obey rules, regulations and instructions, and to carelessness, lack of expertness, negligence, mistake, lack of judgment, absence of supervision and control, exceeding authority, and so on. In a narrow sense these are personal faults. However, they are faults that are inevitable in the handling of material objects by ordinary human beings. The fault cannot be separated from the functioning of the service. Furthermore, the physical injury sustained cannot be amended by an act of a superior, a court decision, or a law. The Council of State has realized this and has refused to divorce personal fault from the functioning of the service except under special conditions, which will be discussed below. Thus, in the Compagnie Générale case, ${ }^{117}$ the court admitted that the accident caused to an individual.by a military automobile was entirely the fault of the driver, yet held the state responsible. The same was held in the Sieur Hacquart case, ${ }^{118}$ when a car was being

\footnotetext{
${ }^{110}$ Rec. Cons. d'Ét. I908, 208. See the remarkable conclusions of M. Tessier, Commissioner of the government, in this case.

${ }^{117}$ Rec. Cons. d'Ét. I923, 372.
} 
driven at excessive speed; and in the Martin-Justet case, ${ }^{119}$ when a soldier was injured in the court yard of the barracks by a bullet fired by one of his comrades, a member of the guard, who was cleaning a loaded gun.

When, however, the act is not performed in connection with materials, supplies, equipment, or construction but is a decision or a ministerial act, the Council of State appears less strict in holding the state liable and more strict in holding the officer liable. When the act of an officer is one of administration, an act of discretion, or an act of decision, the Council of State will sometimes hold the officer liable for faults that are clearly due to his own conduct. Here such questions as the following are raised: Whether the officer has exceeded or is exceeding his jurisdiction; whether the person purporting to act as an officer is one in fact; whether the act is a purely personal one entirely detachable from the official act; whether the act was fraudulent; whether the act constitutes a crime punishable by the ordinary courts. A very few examples will be given.

A defamatory statement contained in a resolution of a municipal council constitutes a personal act, for which the authors may be held personally responsible before the ordinary courts. ${ }^{120}$ When a mayor had trees cut down on property belonging to an individual, after a judicial decision had recognized that the property belonged to the individual rather than to the city, this was considered a personal act. ${ }^{121}$

On the other hand, in the Anguet case, ${ }^{122}$ a person went to a post office, and on attempting to leave, found the door for the public closed, although it was not quite closing time. Upon the request of an employee, he went to a part of the office reserved for the postal personnel, intending to leave by the door used by employees. Two members of the postal service threw him out into the street, injuring his leg. These two employees were convicted before the correctional tribunals. M. Anguet brought a claim for damages before the Council of State. In the opinion which upheld the claim, the Council of State remarked that "the accident of which the plaintiff was the victim, as a result of his brutal expulsion from this part of the office, must be attributed, whatever may be the personal responsibility incurred by the agents, the authors of the expulsion, to the faulty functioning of the public service; that consequently $M$. Anguet has a right to demand from the state reparation for the injury which has been caused him by the accident."

\section{Summary}

The French system of responsibility is particularly important because it has recently been so largely cleared of the dead wood of the past (such as may still be found in various other countries). The system entirely eliminates the doctrine of sovereignty as a reason for non-responsibility. It eliminates the distinction between public or sovereign acts and proprietary or fiscal acts. It does away with distinctions

\footnotetext{
${ }^{219}$ Rec. Cons. d'Et. I9I4, 23I.

${ }^{120}$ Cadot Ville de Marseille, Rec. Cons. d'Et. 1889 , I 488.

221 Mérot Maire de Rosoy, Rec. Cons. d'Et. I910, 937.

122 Rec. Cons. d'Ét. I9Ir, I46.
} 
as to the nature of the officer or the nature of the governmental unit performing the action. It discards the doctrines of principal and agent, and master and servant. It says that the principles of private law are not applicable to the functioning of the state. To a large extent it does away with the idea of fault as a basis for the responsibility of the state, particularly where the fault is practically inseparable from public operations in the realm of mechanical equipment. It does away with the doctrine that the state can do no wrong. It sends the cases where the state, rather than the officer, is liable to administrative tribunals, rather than the regular courts. If there is a conflict as to jurisdiction, it leaves the decision as to whether the case is one involving the responsibility of the state or one involving the responsibility of the officer, to a Tribunal of Conflicts. Finally, it does away with the old system of the "administrative guarantee," or the granting of permission by an administrative advisory body before an officer can be sued.

On the positive side, the present system constitutes a unified pattern of responsibility for all public bodies, governed by exactly the same principles throughout. It develops for the state a public law of responsibility, divorced from the concepts of private law and applied by administrative tribunals. It establishes a doctrine of responsibility which is based to a very large extent upon the principle that the state ought to be liable to the individual for the risks incurred by the functioning of the state services. Expressed in another way, the theory is that in the functioning of the state services, it is inevitable that individuals will be injured, and that compensation for such injuries is a legitimate expense of the state. Some of the most recent cases would seem to base responsibility for exceptional or abnormal injuries upon a rather different principle, that of risk. Examples are: where authorities are dealing with objects such as explosives which are inherently dangerous; or where an authority refused to execute a judgment of a court for fear of a native uprising.

\section{Final Conclusions}

Practical experience shows that the state and its various subdivisions, acting through their various officers and agents, may injure the individual in a wide variety of ways. In respect to these injuries, it is possible for the state to assume very different attitudes. It may conceivably take the attitude of complete irresponsibilty. It may assume responsibility for some acts, but no responsibility for others. Its assumption of responsibility or failure to assume responsibility may be based upon ethical, political, and legal concepts which vary according to economic, political, and social circumstances.

The history of responsibility in the four countries which have been examined directly, as well as in Rome, whose system has been discussed incidentally, shows that, in general, any assumption of responsibility by the state or unit of government has been based on the ethical ground of justice to the individual, and that the conception of such justice has been slowly developing. Refusal to assume responsibility has been based chiefly upon conceptions of political philosophy regarding the nature and functions of the state and its subdivisions, and upon the judicial doctrines flowing therefrom. 
From time to time, certain common threads of thought have been interwoven into the complicated patterns of responsibility which have been developed in various countries.

The first of these ideas, which has been very important in its effects, has been that a distinction should be made between the national or central governments and the local bodies. The reasons given for this distinction have been various. In some countries, such as the United States and Germany before Hitler, the state governments were in most respects sovereign and consequently formulated their own systems of responsibility. Since most local authorities were not considered to be sovereign, the governmental unit to which they were subordinate might impose a system of responsibility upon them. Moreover, the lack of sovereignty in local units made it possible for the courts to develop by judicial decisions a quite different system of responsibility from that existing in sovereign bodies. The breaking away from this distinction by Germany and France marks a great advance in the theory of responsibility.

Perhaps the most important common thread of thought which has dominated thinking on the problem of responsibility in various countries has been the doctrine of sovereignty. Not only its presence or absence in a given unit of government, but its nature and effects, have been the subject of much judicial exposition bearing directly on responsibility. Among the ideas thus developed have been: that since the state can do no wrong, if wrong is done, it is done by officers; that a sovereign body cannot be sued without its express consent; that since the state may sometimes act in a non-sovereign capacity, distinctions may be made between sovereign acts and non-sovereign acts, between public acts and private acts, between the state as fiscus and the state as sovereign, between acts of public power and private acts, between acts performed in a public capacity and those performed in a private capacity, and between acts of "emanations of the Crown" and acts of ordinary authorities. Given the doctrine of sovereignty as an axiom, the metaphysical legends developed by jurists as to when and under what circumstances responsibility for governmental action might be brought about, almost inevitably resulted.

In nearly all countries it has been admitted that the legislative body has authority to subject the state to suit for some sovereign acts, and thus to narrow the field where irresponsibility reigns. In only one of the countries under consideration, namely, France, and there only recently, has the doctrine of sovereignty as a basis for deciding questions of responsibility been done away with.

In all the countries discussed, the problem of the responsibility of officers has been persistent. For a long time, almost the only available redress for tortious action was obtained through holding the officer responsible. In England and France questions arose as to protecting officers from wrongful suits by requiring the consent of the King or the King's Council before suit could be brought. Other questions which have almost universally arisen are: whether fault should be the basis for responsibility; whether all cases against officers should be brought in the regular courts or go to special administrative courts; under what conditions the doctrine of master and servant or the doctrine of respondeat superior should be applied; the distinction be- 
tween nonfeasance and misfeasance; the location of responsibility for ultra vires acts, including in the United States the question of liability for unconstitutional acts; the distinction between ministerial acts and mandatory acts; the responsibility of a superior officer for the acts of an inferior, and so on.

Due to the persistence of the doctrine of sovereignty and its corollaries, and to the various judicial doctrines that have grown up in respect to the responsibility of the state and its officers, great injustice is done to many individuals in connection with the functioning of the modern state. Most of the difficulties that have arisen in the past could be avoided by the establishment of a proper ethical and legal basis for responsibility. Space does not permit a long discussion of the way out. A few suggestions, however, may be made.

In the first place, a scientific and just system of responsibility cannot be established by judicial action in England and the United States, where the doctrine of stare decisis exists. Such a system can be brought about in these countries only by constitutional or legislative action. In France, where the courts are not governed by the doctrine of stare decisis, administrative judicial action has done much to improve the system.

In the second place, a basis for responsibility should be established that is broad enough to cover all divisions of government and public bodies. This has been done in Germany by making all public bodies responsible for the acts of their agents, with the possibility of obtaining legal redress from the culpable officer under appropriate conditions. It has been accomplished in France by the doctrines of fault of service, personal fault, and risk. It has not been accomplished at all in England and the United States.

Finally, the responsibility of all units of government should be based upon the insurance principle. It is absolutely certain that in connection with their functioning, the state and each of its subdivisions will injure a certain number of individuals. The burden of this injury should be considered a legitimate public expense, incidental to carrying on the complicated public functions. This burden, under modern conditions, should not be borne by the officer, for many reasons-the fact that his fault may be very slight and yet the results may be very serious, a situation which will mean injustice to either the officer or the injured person unless the responsibility is borne by the government; the fact that even if the officer is greatly at fault, it does not follow that he is solely so, or that the government should disclaim responsibility for his acts; the fact that a judgment against the officer is not a protection to the individual, since the officer may have no money or property. In short, there is no way of assuring a maximum of justice and a minimum of suffering, except the assumption of responsibility by the unit of government, on the insurance principle. ${ }^{123}$ In case of gross negligence, the officer might still be subjected to penalties; but in case his fault were merely a formal one, such as the mistaken use of private property which he thought to be public property, both he and the injured individual would be protected through the acceptance of responsibility by the government.

\footnotetext{
${ }^{123}$ In the case of small government units, some sort of insurance against liability should be provided, either by a system of state insurance or by participation in a mutual or even a private insurance concern.
} 